\title{
The use of Japanese politeness markers by university students
}

\author{
Rina Supriatnaningsih ${ }^{1}$, Rustono ${ }^{2}$, Edi Astini ${ }^{3}$, Tatang Hariri ${ }^{4}$ \\ rinasupriatnaningsih@mail.unnes.ac.id ${ }^{1}$,rus_tono58@yahoo.co.id ${ }^{2}$, ediastini@gmail.com ${ }^{3}$, hariri39@ugm.ac.id ${ }^{4}$ \\ Universitas Negeri Semarang, Faculty of languages and arts, Indonesia ${ }^{1}$, Universitas Negeri Semarang, Graduate School, \\ Indonesia $^{2}$, Universitas Negeri Semarang, Graduate School, Indonesia ${ }^{3}$, Universitas Gadjah Mada, Yogyakarta, Indonesia ${ }^{4}$
}

\begin{abstract}
Japanese has a respectful form or keigo in five types i.e. sonkeigo, kenjogo I, kenjogo II, teineigo, bikago. Teineigo politeness marker requires addition of -masu and desu to each sentence's end. This study aims to describe politeness markers used by learners in their conversation with natives. The data were collected from 80 students of UNNES, UGM, UDINUS and UMY. Recording and interview were used to collect data in natural setting. The result shows that students generally used-desu and-masu. Speaker's expression of discernment like tabun, tabun_deshou,_to omoimasu were not preferred. Apparently most students contended that use of keigo from teineigo type was sufficient to show politeness since it was considered simple and easy. No previous studies examined keigo' relation to speaker's expression of discernment while it is vital in communication with natives. Therefore, speaker's expression of discernment ought to be added into Japanese lesson.
\end{abstract}

Keyword: speaker's expression of discernment, keigo,

\section{Introduction}

Respectful form, keigo, or also called honorific is one of politeness markers in Japanese. It has a very important role in order to harmonize interpersonal relationship and express respect to the addressee. Keigo is used based on factors like personal closeness, social status and role in society (age differences, status, experience, etc.). If used correctly, it makes communication run smoothly thanks to use of appropriate grammar and choice of words towards the addressee. On the contrary, if not used correctly, it may cause a misunderstanding to the interlocutor that the speaker is sometimes unaware of.

Ide suggests that honorific use is like "socio-pragmatic equivalent to grammatical appropriateness". Basic supposition that the main modus for interaction in Japanese society is discernment is derived from basic assumption that honorific constitutes a direct mark to politeness relative to the speaker's social status, the interlocutor or the referent [1]. Yet, Iori et al. stated that expressing politeness in Japanese context concerns not only use of keigo like - desu or -masu with various choice of words or grammatical appropriateness but also the speaker's expression of discernment or hanashite no kimochi o arawasu handan. Japanese people, for example, prefer to use expressions of uncertainty or dantei o sakeru hyougen in their speech. Desu is replaced with deshou tabun (maybe) or tabun.... deshou, tabun ... to omimasu. Thus, Japanese learners should understand well politeness markers both by keigo and the speaker's expression of discernment [2].

A study by Haugh produced a remarkable outcome because it showed foreigners' perception on Japanese language which is somewhat different from the one of native speakers. He noted that the perception towards Japanese communication believed by the Japanese surveyed are thus characterized by the assumption that Japanese communication is vague and indirect. He further reiterated that non-Japanese may perceive certain examples of elliptical or indirect utterances as vague, when Japanese in the same situation would be able to infer and clearly understand the speaker's meaning. Thus, it is not easy to determine whether Japanese is linguistically 
more vague than other languages such as English but there is common agreement in perception that Japanese sounds to be more indirect than English as it has been argued by Haugh [3].

Another study conducted by Cook examined the use of honorific referent in a board meeting in a Japanese company. It was revealed that honorific referent had been used as a request and as a means to describe the third parties not present. The most remarkable characteristic here was found in verbs divided into 2 namely honorific referent (as respect and modest forms) and honorific to interlocutor. These two types of honorific were discussed since honorific referent generally appeared along with - masu in the main clause [4].

Shibamoto and Smith) studied and discovered that Japanese people pay attention to status differences. That's why we often hear people say that "The Japanese are very polite!" Associating honorific directly to politeness goes beyond that example. They concluded that 1) it is necessary to deconstruct honorific ideology in Japanese society; 2) it is important to reveal how honorific ideology is actually recreated; and 3) it is imperative to investigate real practices of honorific referent particularly how honorific is able to map social identity and activities; and how the speaker chooses strategic option and social norms based on honorific in order to reveal social politeness and message in various social context [5].

Dunn analyzed politeness concept given in Japanese business etiquette training in regard to politeness theory from Brown \& Levinson and Ide. Types of politeness that Japanese youth should master were given in this training. Dunn concluded that notion of keii (respect), reigi (etiquette) and teinei (polite) are relatively independent from shinsetsu (kindhearted) and omoiyari (considerate) [6]. Moreover Dunn reiterated that employees ought to be taught how to show respect by using correct honorific, speak appropriately and behave in 'a lovely manner'. It was concluded that no etiquette training could be separated from respect, kindness and manner.

Kiyama, Tamaoka and Takiura examined the applicability of Brown and Levinson's theory on facework in a non-Western culture by conducting a questionnaire survey of native Japanese speakers. Five factors (intrinsic, contextual, power, distance, and gender) deemed to influence facework behavior were studied. The result indicated that factors related to intrinsic content and attitude had stronger influences than those of the inter and intrapersonal factors. They concluded that Brown and Levinson's theory can also be applied to a non-Western culture, which in this case is Japan [7].

In the meantime, Fukushima and Haugh compared emic understanding on attitude and notion of empathy and anticipative inference in Japanese and Chinese Taipei used by 2 different generations. It was discovered that Japanese and Chinese have similarities and differences in conceptualizing im/politeness. One of them is that both Japanese and Chinese speakers regard attentive behavior, empathy and anticipative inference positively that make them sensitive to "politeness". However, further study is needed particularly on interpersonal meta pragmatics such as care, empathy and anticipative inference if we really want to better understand moral base of im/politeness across different languages and cultures [8].

Another relevant study on Japanese politeness was conducted by Liu, Allen. Based on their research, it was concluded that Japanese linguistic politeness is not a simple subject to discuss since there are several influential factors. They are closely related to social rules, direct context in interaction and choice of 
communication strategies usually relying on politeness theory from Brown and Levinson (1978, 1987). Liu and Allen took their data from Japanese TV series [9].

Rashid et al. investigated characteristics of linguistic politeness of Malay tour guides when guiding Japanese tourists in Bandar Melaka, Malaysia. It was revealed that politeness was mostly expressed through the use of teineigo. During the guidance of 17 Japanese tourists which lasted 23 hours, half of 5 licensed tour guides spoke in plain forms, leaving verbs and vocabulary not in compliance with Japanese politeness principles. Therefore, it was highly recommended that Japanese teachers find suitable strategy when making lesson plan for Japanese for Tourism subject [10].

In his research Fernandes (2018) described linguistic politeness found in Japanese Grammar from early $17^{\text {th }}$ century. It described what is now defined as Japanese Politeness Principles or honorifics like keigo, which is academically called Taigū Hyūgen (respectful expression). It is in accordance with Ide's statement (1982, 382) that honorific is a linguistic form which is morphologically refined used to convey polite utterances and that honorific is used not only orally but written as well [11].

\section{Methods}

A phenomenological approach combined with socio-pragmatics was used in this study since it describes phenomena found in the students' speeches when they conversed with Japanese native speaker. As linguistic politeness reflects the speakers' social status, then sociocultural and discourse circumstances are crucial when conducting pragmatic research on politeness. To assure accuracy and avoid bias outcome, this study chose students' conversation in its natural setting as the data. The subjects of this study were 80 students of whom 21 are Japanese learners from UNNES (MPBU), 20 from UGM (MPBG), 19 from UDINUS (MPBUD), and 20 from UMY (MPBUM). Other parties involved are Japanese lecturers from UNNES (DPJU), Japanese lecturers from UGM (DPJG), the ones from UDINUS (DPJUD), the ones from UMY (DPJM), natives from Japanese company (PPJ), native speakers from Nihonggo Partner (PJNP) and apprentice students (MPJ).

Characteristics from their speeches were then analyzed from socio-pragmatics point of view notably in terms of grammatical appropriateness as politeness marker like the Japanese like to use. Recording and interview technique were used to support the data. It was intended to find out should there be any infringement for not using politeness markers either keigo or the speaker's expression of discernment.

\section{Findings and Discussion}

Data of 105 speeches were collected from 80 students. Most students used keigo especially of teineigo type by using -masu or-desu endings. Nonetheless, we cannot say that their speeches were polite simply because these speeches might sound coercive or give no choice to the addressee and did not consider the addressee's feeling.

When stating expression of certainty or dantei o arawasu hyougen to native speakers, these students should have used expression of uncertainty or dantei o sakeru hyougen or hi dantei by adding "._deshou" (maybe _) or "_to omoimasu” at the end of each utterance. Use of “_deshou” (maybe _) or “_to omoimasu” signifies that 
the speaker would like to confirm to his/her addressee whether the speaker's thought is correct or not. The data taken from 4 universities are presented in Table 1.

Table 1. Politeness markers used by the students

\begin{tabular}{|c|c|c|c|}
\hline Respondent & Speech & $\begin{array}{l}\text { Politeness markers } \\
\text { used by students }\end{array}$ & $\begin{array}{l}\text { Politeness markers to be } \\
\text { used along with the } \\
\text { speaker's expression of } \\
\text { discernment }\end{array}$ \\
\hline MPBU 1 & $\begin{array}{l}\text { Sensei, sumimasen, shitsumon } \\
\text { shitemo ii desuka. } \\
\text { "Excuse Ma'am, may I ask you a } \\
\text { question?" }\end{array}$ & desuka (teineigo type) & deshouka (hi dantei) \\
\hline MPBU 2 & $\begin{array}{l}\text { Sensei, sumimasen, dibeeto } \\
\text { (debate) wakekata no koto } \\
\text { shitsumon shitemo ii } \\
\text { desuka. } \\
\text { "Excuse Ma'am, may I ask you } \\
\text { about the debate group?" }\end{array}$ & desuka (teineigo type) & deshouka (hi dantei) \\
\hline MPBU 3 & $\begin{array}{l}\text { Sensei, Dwi san wa kyou kimasen. } \\
\text { Kaze desu. } \\
\text { "Ma'am, Dwi is absent today } \\
\text { because she is sick." }\end{array}$ & $\begin{array}{l}\text { kimasen (teineigo type) } \\
\text { desu (teineigo type) }\end{array}$ & $\begin{array}{l}\text { konai to omoimasu } \\
\text { kaze da to omoimasu (hi } \\
\text { dantei) }\end{array}$ \\
\hline MPBM 1 & $\begin{array}{l}\text { Sensei, wakaranai kota ga mada } \\
\text { arimasuga, shitsumo shitemo ii } \\
\text { desuka. } \\
\text { "Excuse me Ma'am, I don't fully } \\
\text { understand, may I ask ...? }\end{array}$ & desuka (teineigo type) & deshouka (hi dantei) \\
\hline MPBM 2 & $\begin{array}{l}\text { Sensei, shitsumon shimasu .... } \\
\text { "Ma'am, may I ask? }\end{array}$ & desuka (teineigo type) & $\begin{array}{l}\text { Shite mo ii deshouka (hi } \\
\text { dantei) }\end{array}$ \\
\hline MPBM 3 & $\begin{array}{l}\text { Sensei, UAS no tema nan desuka. } \\
\text { "Ma'am, what is the topic for the } \\
\text { final exam? } \\
\text { "Ma'am, everything is expensive } \\
\text { in Japan, right?" }\end{array}$ & desuka (teineigo type) & deshouka (hi dantei) \\
\hline MPBM 1 & $\begin{array}{l}\text { Sensei, sumimasen. A san ni } \\
\text { sitsumon shitemo ii desuka. } \\
\text { "Excuse me Sir, may I ask A?" }\end{array}$ & desuka (teineigo type) & deshouka (hi dantei) \\
\hline MPBG 2 & $\begin{array}{l}\text { Nihon de, donna saigai ga yoku } \\
\text { Okorimasuka. } \\
\text { "What disaster often occurs in } \\
\text { Japan?" }\end{array}$ & $\begin{array}{l}\text { okorimasu (teineigo } \\
\text { type) }\end{array}$ & okoru deshouka (hi dantei) \\
\hline MPBG 3 & $\begin{array}{l}\text { Kozui ga attara takai tokoro ni } \\
\text { Ikimasu. } \\
\text { "When there is flood, (we) will go } \\
\text { to higher place." }\end{array}$ & ikimasu (teineigo type) & $\begin{array}{l}\text { iku deshou (hi dantei) } \\
\text { iku kamo shireasen }\end{array}$ \\
\hline MPBD 1 & $\begin{array}{l}\text { Sensei, shitsumon shitemo ii } \\
\text { desuka. } \\
\text { "Sir, May I ask you a question...? }\end{array}$ & desuka (teineigo type) & deshouka (hi dantei) \\
\hline MPBD 2 & $\begin{array}{l}\text { Sensei, sumimasen, kiitemo ii } \\
\text { desuka. } \\
\text { "Sir, May I ask you a question? }\end{array}$ & desuka (teineigo type) & deshouka (hi dantei) \\
\hline MPBD 3 & Sensei, ukemi no katachi no koto & desuka (teineigo type) & deshouka (hi dantei) \\
\hline
\end{tabular}






As seen in Table 1 all students used keigo (teineigo type) as politeness marker by adding -desu and -masu at the end of their speech. However, none of them used the speaker's expression of discernment since there was not any either deshou or expression of uncertainty hi dantei or dantei o sakeru hyougen. To make our speech polite, we are not supposed to use confirmatory expression (dantei hyougen) just by adding - desu. Instead, we should also use deshou like in Shitsumon shitemo mo ii deshouka (May I ask you?), or iku to omoimasu / iku kamo shiremasen (Maybe we will go to higher place?). Those expressions do not give certainty in order to give the addressee time to think over whether he/she agrees or not with what is asked. Moreover, the speaker should also have used expression of possibility by adding ... to omimasu atsu ....kamo shiremasen.

\section{Conclusion}

Of 105 utterances analyzed, 80 utterances contain politeness markers of desu and masu (teineigo type). Nonetheless, there are 25 utterances without politeness markers at all. Use of desu and masu does not guarantee politeness because there's no speaker's expression of discernment. The result of this research suggests that we should not view Japanese politeness learning only from keigo point of view but also from the speaker's expression of discernment. Besides, it should also be taught to students upon completion of keigo lesson as supplementary material to Japanese politeness subject.

\section{References}

[1] S. Ide, "Formal forms and discernment: two neglected aspects of universals of linguistic politeness," Multilingua, Vol. \%1 dari \%28-(2/3), pp. 223-248, 1989.

[2] I. Iori, S. Takanashi, K. Nakanishi dan T. Yamada, Shokyuu o Oshieru Hito no Tameno Nihongo Bunpoo Handobokku, Tokyo: 3A corporation, 2009.

[3] M. Haugh, "Revisiting the conceptualization of Politeness Japaness," Multilingua, vol. 23, pp. 1-27, 2004.

[4] H. M. Cook, “Are Honorifics Polite? Uses of Referent Honorifics in a Japanese Commitee Meeting," Journsal of Pragmatic, vol. 43, pp. 3655-3672, 2011.

[5] J. S. S. Shibamoto, "Honorifics, "Politeness and Power in Japanese Political Debate," Journal of Pragmatics, vol. 43, pp. $3707-3719,2011$.

[6] C. D. Dunn, "Formal forms or verbal strategies? Politenesstheory and Japanese Busines Etqeuette Training," Jounal of Pragmatics, vol. 43, pp. 3643-3654, 2011.

[7] S. T. K. T. M. Kiyama, “Applicability of Brown and Levinson's Politeness Theory to a Non-Western Culture:Evidence from Japanese Facework Behavior,” SAGE Open, 2012. 
[8] C. D. Dunn, "Speaking Polite, Kindly, and Beatufully: Idielogies og Politeness in Japanese Business Etiquette Training," Multilingua, vol. 32, pp. 225-245, 2013.

[9] X. d. A. T. J. Liu, “A Study of Linguistic Politeness in Japanese,” Open Journal of Modern Linguistics, vol. 4, pp. 651663, 2014.

[10] A. Rashid, I. Ismail, I. R dan R. Mamat, "Ketidaksantunan dalam Perbualan Bahasa Jepun oleh Pemandu Pelancong Malaysia,” GEMA online Journal of Language Studies, vol. 17, 2017.

[11] G. Fernandes dan A. Carlos, "First Grammatical encoding of Japanese Politeness (17 th Century)," Bol.Mus.Para.Emilio Goeldi. Ciene. Hum. Belem, vol. 13 (1), pp. 187-203, 2018. 